\title{
THE ISOPOD GENUS ICHTHYOXENUS. HERKLOTS, WITH DESCRIPTION OF A NEW SPECIES FROM JAPAN.
}

\section{By Harriet Richardson,}

Collaborator, Division of Marine Invertebrates, United States National Museum.

In 1870 Herklots ${ }^{1}$ described the type-species of the genus Ichthyoxenus which was found parasitic on the fish Barbodes maculatus Bleeker from Java. The mode of life of this isopod is peculiar and interesting. It bores a hole in the body of the fish just back of the lateral fin, where it lives with its mate. It enters this cavity when young. As it grows in size, it is unable to leave the body of the fish and becomes many times larger than the opening through which it entered. This species was named after Mr. Jellinghaus, who was the first to notice the parasite, which he called "songkeat," and who in 1860 wrote a note concerning it to the Société physique des Indes néerlandaises. ${ }^{2}$ The fish was taken from the River Tjikerang, district of Tjilokotot, regency of Bandong.

The second species of the genus, Ichthyoxenus montanus, was described by Schiœdte and Meinert ${ }^{3}$ in 1884. It was found on Puntius sophores in the Himalayan Mountains.

Up to the present time these two were the only species known.

In 1908 Maj. P. A. Ouwens ${ }^{4}$ mentioned another host for Ichthyoxenus jellinghausii, the fish Nemacheilus fasciatus van Hasselt, from the Tji-Seroema near Batavia.

Not long ago Dr. Harold Heath wrote to me concerning some parasites which were found on Japanese fishes from Lake Biwa. They were described as living in the body of the fish, which they entered through a hole bored just back of the lateral fin. The specimens were sent to the United States National Museum by Mr. Will Thompson, and the parasites proved to be a new species of Ichthyoxenus. The hosts are Acheilognathus rhombeum (Schlegel),

1 Archives Néerlandaises des Sciences, vol. 5, 1870, pp. 128-137, pl. 5, figs. 10-18.

2 Natuurk. Tijdschr. Nederl.-Indië, vol. 22, 1860, p. 378.

3 Nat. Tidsskrift (3), vol. 14, 1884, pp. 303-309, pl. 11, figs. 10-11.

4 Natuurk. Tijdschr. Nederl.-Indië, vol. 67, 1908, pp. 29-35. 
Gnathopogon elongata (Schlegel), Acheilognathus tabira Jordan and Thompson, MSS., Acheilognathus lanceolatum (Schlegel), and Acheilognathus cyonostigma (Jordan and Fowler). I have since found this parasite on A. limbatum Jordan and Snyder from the same locality.

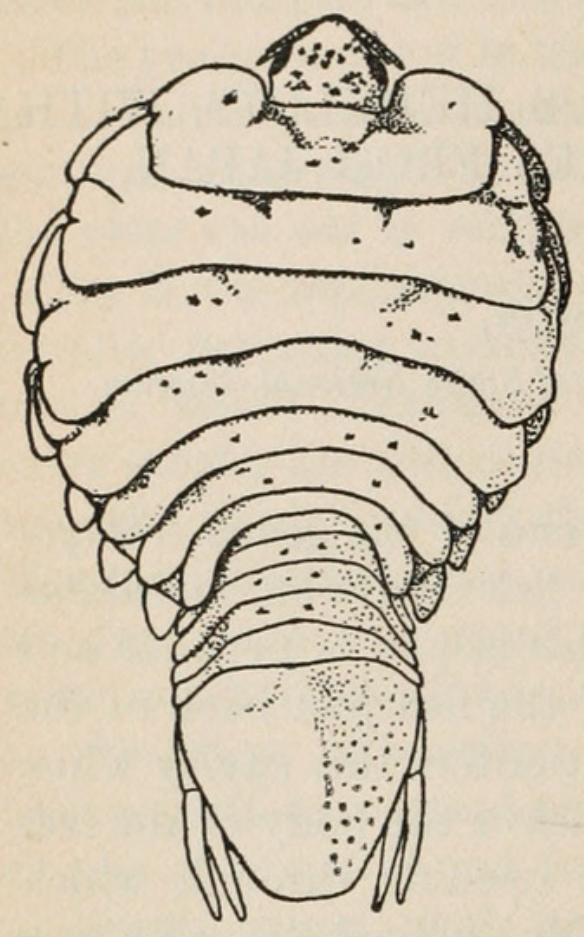

Fig.1.-IChthyoXenUs JellinghaUsi, Buitenzorg. Female. $\times 3 \frac{1}{3}$.

\section{ICHTHYOXENUS JELLINGHAUSII Herklots.}

Ichthyoxenus jellinghausii HeRкLотs, Archives Néerlandaises, vol. 5, 1870, pp. 128-137, pl. 5, figs. 10-18.-Schicdte and MeinERT, Naturhistorisk Tidsskrift (3), vol. 14, 1884, pp. 298-303, pl. 11, figs. 5-6.-MAX Weber, Zool. Ergebnisse, vol. 2, 1892, pp. 557-560, pl. 30, fig. 1.-WILlink, Natuurk. Tijdschr. Nederl.-Indië, vol. 64, 1905, pp. 156-161.-Ouwens, Natuurk. Tijdschr. Nederl. Indië, vol. 67, 1908, pp. 29-35.

Locality.-A male and a female, collected by Dr. Owen Bryant and Mr. William Palmer in Java, are in the United States National Museum. The host is not known.

This species has been recorded from Bandong and Batavia. The specimen in the United States National Museum is from Buitenzorg, and if the figures of Herklots and Schiœdte and Meinert are correct it differs from the type in the following points: The first

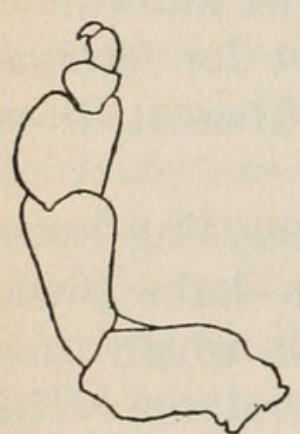

Fig.3.-ICHTHYoxenus JELLINGHAUSII, BUITENZORG. SEVENTH LEG OF FEMALE. $\times 7 \frac{1}{4}$. segment of the thorax in the female has the anterior margin deeply excavate in the middle, the excavation being rectangular; the seventh

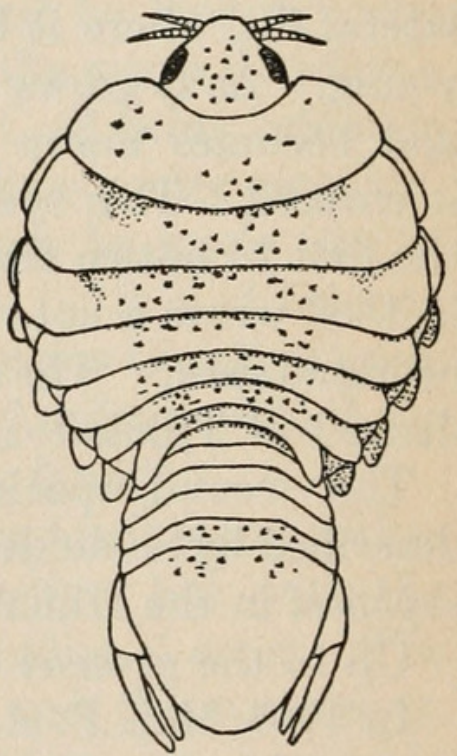

Fig. 2.-ICHTHYoXenUS JELLINGHAUSI, BUITENZORG. MALE. $\times 5 \frac{1}{7}$. pair of legs have the carpus and merus very much inflated, with the inner margin produced in a rounded expansion; the merus is also much elongated.

For the purpose of comparison with the new species from Japan, I have figured the specimen in the United States National Museum, which I have identified as Ichthyoxenus jellinghausii Herklots. Since I have not seen the typespecies and find the Buitenzorg specimens so close to the description and figures of this form, I have thought it best to do this. 
ICHTHYOXENUS JAPONENSIS, new species.

Body of female oblong-ovate, almost twice as long as wide, 13 $\mathrm{mm}$. long, $7 \mathrm{~mm}$. wide. Surface smooth. Color pale yellow, with scattered black dots.

Head small, triangular, $2 \mathrm{~mm}$. long, $2 \frac{1}{2} \mathrm{~mm}$. wide; front rounded. Eyes large, oblong, about $1 \mathrm{~mm}$. in length and separated by a distance equal to $1 \mathrm{~mm}$. or the length of one eye. First antennæ short, composed of six articles and extending to the middle of the eye or to the end of the fifth article of the second antennæ. Second antennæ composed of seven articles and extending almost to the post-lateral angle of the head.

The first segment of the thorax is about twice as long in the median line as any of the three following, being $1 \frac{1}{2} \mathrm{~mm}$. in length. The second, third, and fourth segments are subequal. The last three segments gradually decrease in length, the three together measuring $1 \frac{1}{2} \mathrm{~mm}$. The anterior margin of the first segment is sinuate in the middle, the lateral parts projecting laterally beyond the

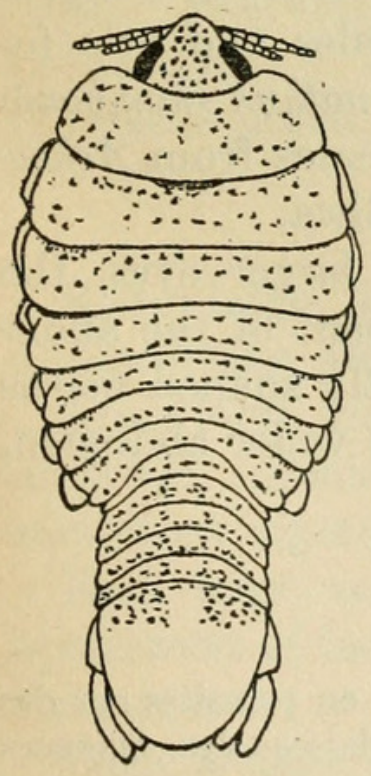

Fig. 5.-ICHTHYOXENUS JAPONENSIS, LAKE BIWA, FROM ACHEILOGNATHUS LIMBATum. Male. $\times 5 \frac{1}{7}$. head and being posteriorly constricted. Epimera are present on the last six segments, those of the second, third, and fourth segments

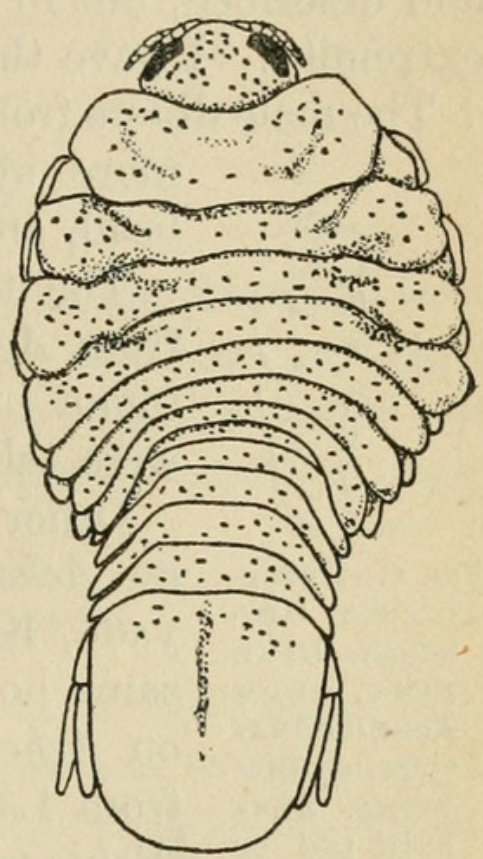

Fig. 4.-ICHTHYOXENUS JAPONENSIS, LAKE BIWA, FROM ACHEILOGNATHUS CYONOstigma. Female. $\times \mathbf{5}$. being narrow, elongate plates occupying the anterior half of the lateral margin; those of the last three segments are about as long as wide, with the posterior extremities rounded, and are placed just anterior to the lateral margin of their respective segments.

The abdomen is deeply immersed in the thorax, the lateral parts of the first two segments being completely covered on one side, the second segment partly showing on the other side. The first five segments gradually increase in length, all together measuring $2 \frac{1}{2} \mathrm{~mm}$. The sixth or terminal segment is a little longer than wide, $4 \frac{1}{2}$ $\mathrm{mm}$. long, $4 \mathrm{~mm}$. wide, and is posteriorly widely rounded. Its posterior half is thin, semitranslucent, and colorless, with no markings. The uropods are much shorter than the terminal segment of the abdomen, and do not reach its extremity by a distance equal to $1 \mathrm{~mm}$; the branches are equal in length, narrow, tapering, with rounded extremities, the outer one being slightly narrower than the inner one. The pleopods are also short, not quite reaching the 
tip of the uropods and being $1 \mathrm{~mm}$. shorter than the extremity of the terminal abdominal segment.

All seven pairs of legs are prehensile. The last pair has the carpus and merus dilated in rounded expansions on the inferior side. The merus is short, being about one-third the length of the ischium. In the last four pairs of legs these articles show an increasing expansion.

Some of the specimens obtained are larger than the one figured and described, but in most of these the abdomen is curled up at the extremity. I have therefore taken the smallest one as the type.

The male differs from the female in size, being much smaller; in the more symmetrical body, longer antennæ, narrower

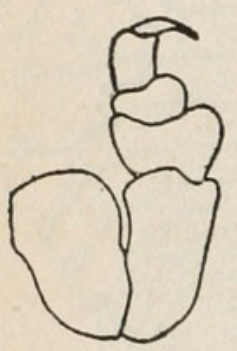

FIG. 6.-ICHTHYOXENUS JAPONENSIS, LAKE BIWA, FROM ACHEILOGNATHUS CYONOSTIGMA. SEVENTH LEG OF FEMALE. $\times 14 \frac{1}{2}$. head, and smaller terminal segment of the abdomen.

The type-specimens, male and female, were taken from Acheilognathus cyonostigma (Jordan and Fowler), found in Lake Biwa, and two males and two females were taken from the same host at Omi, Lake Yogo.

Other specimens are as follows: A male and a female on Acheilognathus lanceolatum (Schlegel) from Funayado, Kiusiu, Japan, and a male and a female on the same host from Omi, Lake Yogo; a male and a female on Acheilognathus tabira Jordan and Thompson, MSS., from Lake Biwa; one female on Gnathopogon elongata (Schlegel) from Lake Biwa; two males and two females from two specimens of Acheilognathus rhombeum (Schlegel) from Lake Biwa; two males and two females from Acheilognathus limbatum Jordan and Snyder from Lake Biwa.

This species differs from I. jellinghausii in the larger eyes, the larger and more circular form of the terminal segment of the abdomen, the shorter uropoda, the shorter and differently shaped merus of the seventh pair of legs, and the larger head and wider abdomen, compared with the thorax.

Type.-Cat. No. 45617, U.S.N.M.

\section{LIST OF REFERENCES.}

Herklots, J. A. Deux nouveaux genres de Crustacés vivant en parasites sur des poissons-epichthys et ichthyoxenos. Archives Néerlandaises des Sciences exactes et naturelles, vol. 5, 1870, pp. 120-137, pl. 5, La Haye.

Ouwens, P. A. Nog iets over Ichthyoxenus jellinghausii(Herklots). Natuurkundig Tijdschrift voor Nederlandsch-Indië, vol. 67, 1908, pp. 29-35, Weltevreden.

Schiedte, J. C., and Meinert, Fr. Symbolæ ad monographiam cymothoarum crustaceorum isopodum familiæ. IV. Cymothoidæ. Trib. II. Cymothoinæ. Trib. III. Livonecinæ. Naturhistorisk Tidsskrift (3), vol. 14, 1884, pp. 221-421, pls. 6-18, Kjøbenhavn.

Weber, Max. ${ }^{1}$ Die Süsswasser-Crust. des Indischen Archipels, nebst bemerkungen über die Süsswasser-Fauna im Allgemeinen. Zool. Ergebnisse, vol. 2, 1892, pp. 557-560, pl. 30, fig. 1, Leiden.

Wrilink, H. D. Tieenk. De "Songkeat" een vischparasiet. Natuurkundig Tijdschrift voor Nederlandsch-Indië, vol. 64, 1905, pp. 156-161, Amsterdam. 


\section{$2 \mathrm{BHL}$ Biodiversity Heritage Library}

Richardson, Harriet. 1913. "The isopod Ichthyoxenus Herklots, with description of a new species from Japan." Proceedings of the United States National Museum 45, 559-562. https://doi.org/10.5479/si.00963801.45-1995.559.

View This Item Online: https://www.biodiversitylibrary.org/item/31799

DOI: https://doi.org/10.5479/si.00963801.45-1995.559

Permalink: https://www.biodiversitylibrary.org/partpdf/24713

\section{Holding Institution}

Smithsonian Libraries

\section{Sponsored by}

Smithsonian

\section{Copyright \& Reuse}

Copyright Status: NOT_IN_COPYRIGHT

This document was created from content at the Biodiversity Heritage Library, the world's largest open access digital library for biodiversity literature and archives. Visit BHL at https://www.biodiversitylibrary.org. 